\title{
Slope Stability and Erosion-Sedimentation Analyses Along Sub- watershed of Muara Bangkahulu River in Bengkulu City, Indonesia
}

\author{
Lindung Zalbuin Mase \\ Department of Civil Engineering, Faculty of Engineering, University of Bengkulu, 38371 A Bengkulu, Indonesia.
}

\begin{abstract}
Within last 10 years, high intensity of rainfall had triggered the increase of water level during floods along Sub-watershed of Muara Bangkahulu River, Bengkulu, Indonesia. The high rainfall intensity was caused by extreme weather change. This study was focused on a segment of Muara Bangkahulu Subwatershed called Semarang Segment. This segment is one of socio-economy centres in Bengkulu City. This study was initiated by performing the environmental investigation and collecting the rainfall intensity data in the study area. The site investigation data and soil tests were also performed to obtain the soil properties along sloping ground of sub-watershed. The analysis to obtain the maximum flood discharge as well as the maximum water level within 10 years was conducted. Furthermore, the slope stability analysis using both finite element and limit equilibrium methods was performed. In general, the results of this study could be a recommendation to stakeholders to consider the future impact in the study area. The results of this study could also bring a recommendation for the slope protection in the study area.
\end{abstract}

\section{Introduction}

Bengkulu City (Figure 1) is a capital city of Bengkulu Province in Indonesia. This city is categorised as one of most vulnerable areas to natural disasters in Indonesia [1]. Several natural disasters such as earthquakes, floods, climate changes, and droughts could happen in this city. Flood is one of most frequently natural disasters which occurs in Bengkulu City every year. During 28-29 April 2019, a high rainfall intensity occurred massively in Bengkulu Province (Figure 2). It was furthermore triggering the flooding in Bengkulu City. This event was later known as the 2019 Bengkulu Flood.

In the mountainous area, the high rainfall intensity due to the extreme weather (as the impact of climate change) had resulted in the large accumulated amount of flood volume. Illegal logging and coal mining without consideration of environment rebuilding were also the main reasons why flood frequently occurred in Bengkulu City. Bengkulu City, which is located at a low terrain area, is crossed by the main river of Bengkulu City. This river is known as Muara Bangkahulu River. During the 2019 Bengkulu Flood, several areas along Muara Bangkahulu River were inundated. Thousands of people were evacuated during the flood.

Bengkulu City is a part of Muara Bangkahulu Subwatershed, which is known as Air Bengkulu Sub- watershed. This sub-watershed is frequently experiencing floods in Bengkulu City every year [2]. The population is also centralised along this Subwatershed. A segment known as Semarang Segment of Air Bengkulu Sub-watershed is categorised as a dense population area in Bengkulu City. During the 2019 Bengkulu Floods, this segment was identified as the most impacted area. Disaster Prevention Agency of Bengkulu City or BPBD [3] reported that hundreds of houses were inundated and Hundreds of hectares of farming fields were also inundated during the 2019 Bengkulu Flood. BPBD [3] reported that the 2019 Bengkulu Flood is the worst flood occurred in Bengkulu City after the 1989 Bengkulu Flood. After the flood, the slope failures along Muara Bangkahulu River was identified. The high excess pore pressure was indicated as main factor why several river slopes failure.

This paper presents a study of slope stability along Semarang Segment of Muara Bangkahulu Subwatershed, especially due to the 10 years rainfall intensity period in Bengkulu City. The soil sampling on the slope along Semarang Segment was performed. Furthermore, the physical and engineering properties were performed. The analysis of peak discharge was also performed to estimate the maximum water level due to the maximum discharge in Semarang Segment. Slope stability analysis using limit equilibrium method and

\footnotetext{
* Corresponding author: $\underline{\text { lmase@unib.ac.id }}$
} 
finite element method is performed. Factor of Safety $(F S)$ for slope and the possible deformation were presented. In general, this study could describe slope stability along Semarang Segment. The results of this study could be also a recommendation to stakeholders and local government of Bengkulu Province, especially for slope failure prevention and water conservation along Semarang Segment in Bengkulu City.

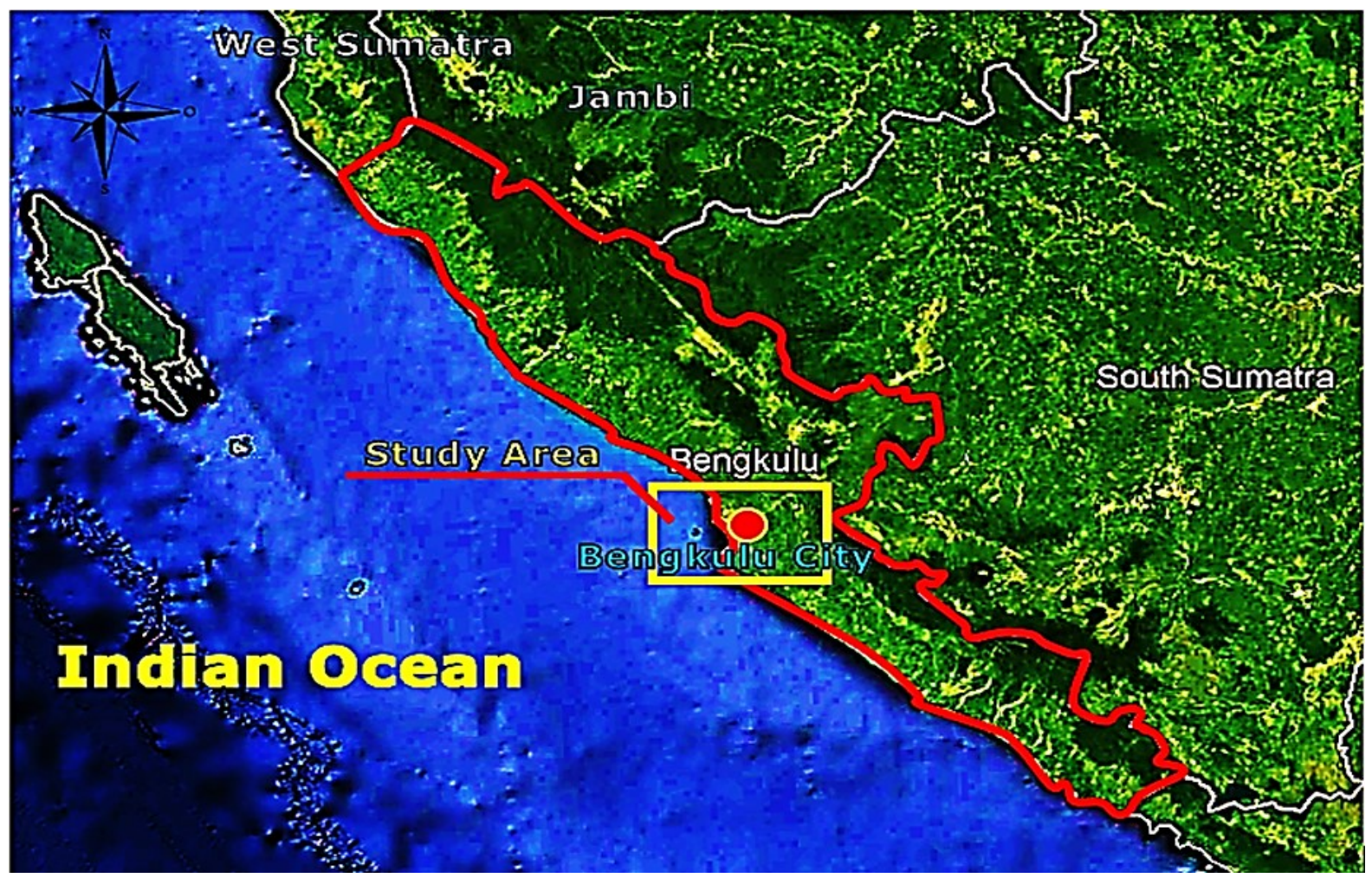

(a)

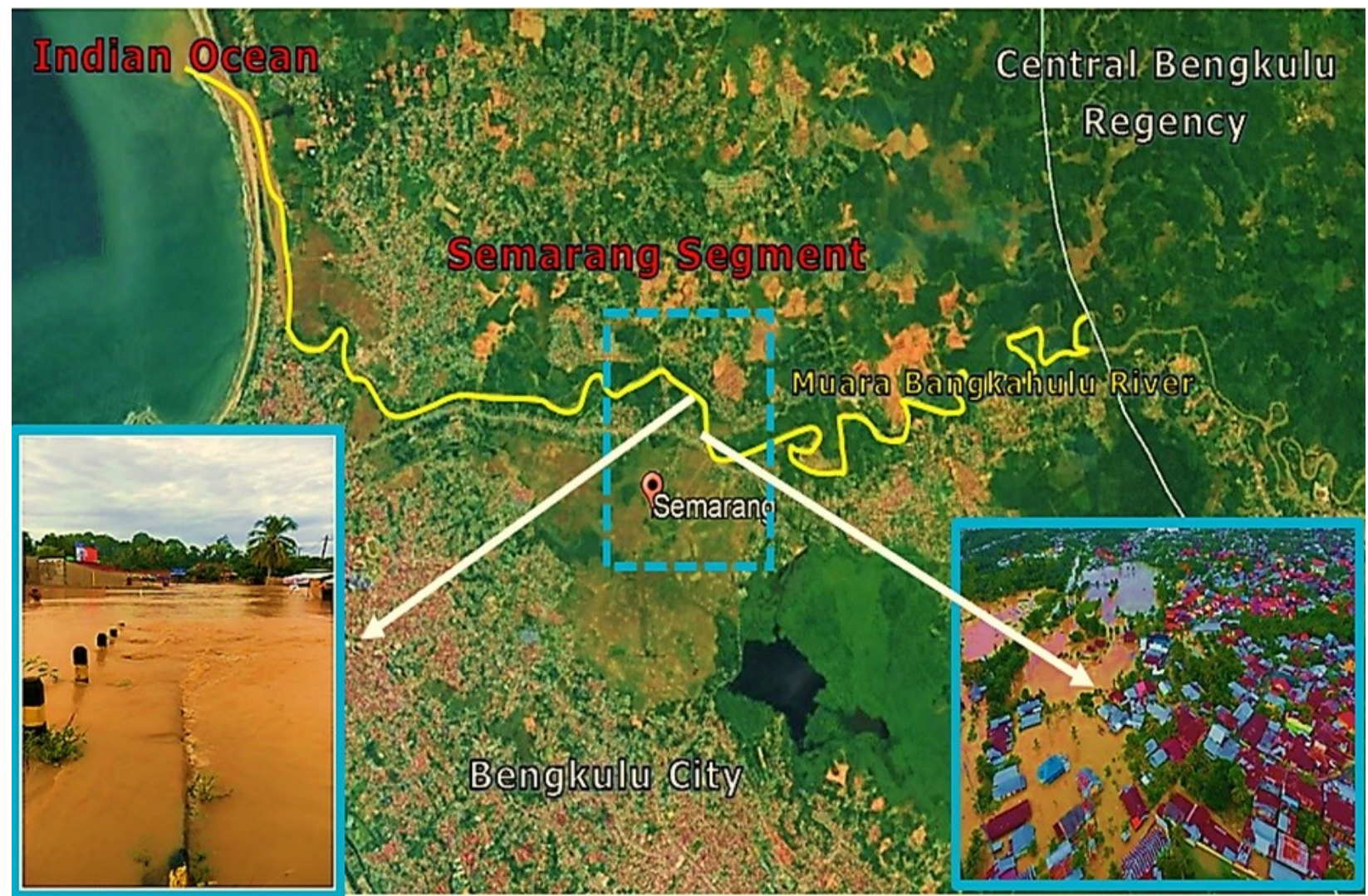

(b)

Fig. 1. Flood in Bengkulu City on 28-29 April 2019 (a) location of study area (b) Muara Bangkahulu Sub-watershed

\footnotetext{
* Corresponding author: $\underline{\text { lmase@ } @ \text { unib.ac.id }}$
} 


\section{Study Area}

This study is focused on the Semarang Segment, Bengkulu City, Bengkulu Province, Indonesia. This Segment is a part of Air Bengkulu Sub-watershed (Figure 2). During 28-29 April 2019, this area was categorised as the most impacted area due to floods. Several housing areas and government infrastructures were submerged and thousands of people had to be evacuated. In this segment, slope failures were also observed. In Figure 2, 10 cross sections were selected. Those cross-sections are named as CS-1 to CS-10. Those cross-sections represent the slope zone in Semarang Segment. Based upon the observation, those crosssections were the failure slopes during the flood on 2829 April 2019. The descriptions of cross sections are also presented in Figure 2. In general, the height of slopes along Muara Bangkahulu River in Semarang Segment ranges from 4 to $6 \mathrm{~m}$. The slopes width is about 4.5 to 13 $\mathrm{m}$. The slopes angle of Semarang Segment is varied from $41.655^{\circ}$ to $24.788^{\circ}$. In cross-sections area, the site investigation was performed. The site investigation includes the undisturbed sampling, measurement of slope geometry, etc. Furthermore, undisturbed samples were brought to the laboratory for the further investigation. The physical properties and engineering properties were then investigated. The detail of site investigation for the typical soils in the study area is presented in Table 1.

Based on the soil properties, the soil on the study area was generally dominated by sandy soil. This sandy soil was classified as silty sand, which was symbolised as SM based on Unified Soil Classification System [4]. The density of soil under dry condition to saturated condition ranges from $12.175 \mathrm{kN} / \mathrm{m}^{3}$ to $19.906 \mathrm{kN} / \mathrm{m}^{3}$. The low dry density $\left(\gamma_{\mathrm{d}}\right)$ indicated that the material was relatively loose [5]. It also indicated that this sandy soil was relatively very vulnerable to be eroded by surface runoff [6]. The large void ratio (e), i.e. 1.131 indicated that the soil was not well compacted. The degree saturation of soil was about $98 \%$. It reflects that the soil sampling was almost totally saturated. In addition, this sandy soil tends to have small soil strength. In Table 2, the soil cohesion is about $3.874 \mathrm{kN} / \mathrm{m}^{2}$ whereas the internal friction angle is about $29.321^{\circ}$. The investigation to the consistency of fines content in the soils was also observed. Liquid limit (LL) and Plastic Limit (PL) were $43.161 \%$ and $36.986 \%$, respectively. Therefore, based on those values, the sandy soils tend to have low plasticity index (PI), i.e. about $6.716 \%$. The coefficient permeability $(\mathrm{k})$ is about $0.5 \mathrm{~cm} /$ hour.

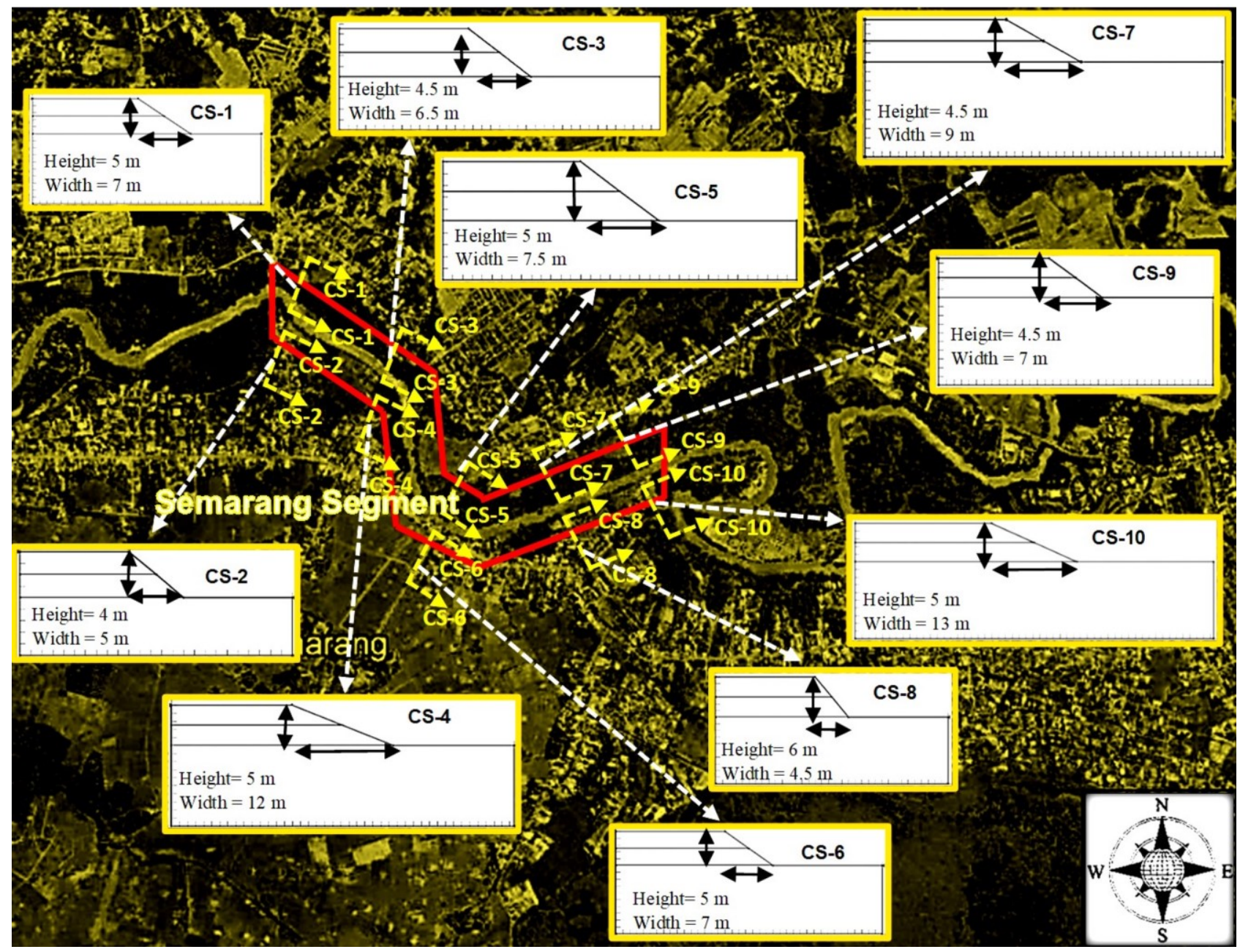

Fig. 2. Study area

\footnotetext{
* Corresponding author: $\underline{\text { lmase@unib.ac.id }}$
} 
Table 1. Typical soil properties

\begin{tabular}{|c|c|c|c|c|}
\hline No. & Soil Properties & Notation & Value & Unit \\
\hline 1 & Soil Type (USCS) & SM & - & - \\
\hline 2 & Bulk Density & $\gamma_{b}$ & 17.310 & $\mathrm{kN} / \mathrm{m}^{3}$ \\
\hline 3 & Dry Density & $\gamma_{d}$ & 12.175 & $\mathrm{kN} / \mathrm{m}^{3}$ \\
\hline 4 & Saturated Density & $\gamma_{s a t}$ & 19.906 & $\mathrm{kN} / \mathrm{m}^{3}$ \\
\hline 5 & Water Content & $w$ & 42.174 & $\%$ \\
\hline 6 & Specific Gravity & $G_{s}$ & 2.645 & - \\
\hline 7 & Void Ratio & $e$ & 1.131 & - \\
\hline 8 & Degree of Saturation & $S$ & 0.98617 & $\%$ \\
\hline 7 & Liquid Limit & $L L$ & 43.161 & $\%$ \\
\hline 8 & Plastic Limit & $P L$ & 36.986 & $\%$ \\
\hline 9 & Plasticity Index & $P I$ & 6.176 & $\%$ \\
\hline 10 & Cohesion & $c$ & 3.874 & $\mathrm{kN} / \mathrm{m}^{2}$ \\
\hline 11 & Internal Friction Angle & $j$ & 29.3212 & $\circ$ \\
\hline 12 & Coefficient Permeability & $k$ & 0.500 & $\mathrm{~cm} / \mathrm{hour}$ \\
\hline & & & & \\
\hline
\end{tabular}

\section{Theory and Methodology}

\subsection{Background of Muara Bangkahulu River}

As a part of Muara Bangkahulu Watershed, Bengkulu city is almost periodically experiencing the flood every year. Every raining season, the high rainfall intensity could trigger flood event in Bengkulu City. The extreme weather had implicated to Bengkulu Province and its surrounding areas. As no adaptations implemented to reduce the impact of high rainfall intensity, the floods are still frequently occurring in Bengkulu City.

Within last three decades, at least two massive floods occurred in Muara Bangkahulu Watershed. The floods were generally started by high rainfall intensity in the upstream of Muara Bangkahulu River, which was located in Central Bengkulu Regency [7]. In 1989, a massive flood initiating by rainfall in the upper stream had resulted a large inundation in Bengkulu City, as reported by Mase et al. [8]. It has been known that the environmental damages in the upstream area is suspected as the main reason why floods could happen annually in Bengkulu City. In the upstream the illegal logging, massive coal mining, and degradation of river function were identified as the main factors. Amri et al. [9] mentioned that those main factors had contributed to the massive erosion and sedimentation along Muara Bangkahulu River. The impact would be getting worse once the change of land use occurred in the downstream area, especially the change of catchment area to the housing area. In Air Bengkulu Sub-watershed, this phenomenon was commonly observed. Thousands of people prefer to choose this area and tend to ignore the possible impact in the future. Putrie et al. [10] mentioned that there is a significant increase on the population along Sub-watershed area in Bengkulu City.

The erosion and sedimentation had been identified as the main problem in Muara Bangkahulu Subwatershed. Mase [11] mentioned that the contribution of erosion and sedimentation could decrease wet crosssectional area of the river. The decrease of wet cross- sectional area would result in the inundation on the low terrain area, such as Bengkulu City. During the floods, along Muara Bangkahulu River, especially Semarang segment frequently underwent the slope failure due to excess pore water pressure. Semarang Segment, which was also the main segment of Air Bengkulu Subwatershed, was one of the developed areas in Bengkulu City. In general, this area was the catchment zone of Muara Bangkahulu River. It means that this area was not recommended for the housing area. As the land prince in this area was relatively chief, people inclined to be more interested in choosing this segment for housing area. However, the understanding on the effect of flood and slope failure in this segment has not totally achieved people living in this segment. So far, the study of slope stability along Muara Bangkahulu River, especially Semarang Segment has still rarely performed.

\subsection{Erosion and Sedimentation Analyses}

Universal Soil Loss Equation (USLE) developed by Winschmeier and Smith [5] is a widely used method to predict the erosion level. USLE is one of erosion models, which is formulated to predict the long-term erosion average from the sheet and rill erosion. This method is also able to predict the gully erosion on the certain conditions. USLE equation can be expressed in the following,

$$
A=R \cdot K \cdot L_{S} \cdot C \cdot P
$$

where, $A$ is average annual soil loss in t/a (tons per acre), $R$ is rainfall erosivity index, $K$ is soil erodibility factor, $L_{S}$ is topographic factor for slope, $C$ is cropping factor, and $P$ is conservation practice factor.

Van Santen et al. [12] mentioned that sedimentation is a physical process to remove the soil particles from a location to other locations, which were eroded in a watershed area. Due to the gravity process, those particles were sedimented into the river bed. A part of sediments would settle into river bed and it would be transported to watershed area. Another part would gravitate along the surface flow path on the toe of slope. Generally, it could be concluded that the sediment was a result of erosion process. The method to estimate sedimentation had been proposed by Auserwald [13]. This method has commonly known as sedimentary delivery ratio or $S D R . S D R$ is a ratio which reflects the amount of transported sediment to the river against the amount of occurred erosion in a Sub-watershed. The SDR formulation is presented in the following equation

$$
S D R=-0.02+0.385 \cdot A_{s}^{-2}
$$

where, $A_{s}$ is watershed area in acre. Asdak [14] proposed a correlation to estimate the total amount of sedimentation $(Y)$ by this following equation

$$
Y=E \cdot(S D R) \cdot A
$$

where, $E$ is total of erosion (ton/acre/year)

\footnotetext{
Corresponding author: $\underline{\text { lmase } @ \text { unib.ac.id }}$
} 


\subsection{Slope Stability Analysis}

On a slope, the gravitation element could lead a slope to be sliding down. If the gravitation element is larger than the shear strength, a slope failure can happen. An analysis to the slope stability is widely known as slope stability analysis. Slope stability analysis is normally difficult to perform as many factors including geometry, climate, human activity, physical and engineering properties of soils, etc. Many methods to estimate slope stability had been proposed by several researchers. Bishop [15] mentioned that slope stability could be estimated by a method of slices. This method is also known as a Bishop simplified method. This method is also categorised as one of limit equilibrium methods. Bishop [15] also mentioned that the minimum factor of safety $(F S)$ of 1.5 is required to define a stable slope. For $F S$ less than 1.5, a slope is defined as unstable slope. In the analysis, Bishop [15] considered that total forces on vertical direction has no resultant forces. The formulation of slope stability based on Bishop [15] method is expressed in the following equation,

$$
F S=\frac{\sum_{i=1}^{i=n}\left[c^{\prime} b_{i}+W_{i}\left(1-r_{u}\right) \tan \phi^{\prime}\right]\left(\frac{1}{\cos \theta_{i}\left(1+\frac{\tan \theta_{i} \tan \phi^{\prime}}{F S}\right)}\right)}{\sum_{i=1}^{i=n} W_{i} \sin \theta_{i}}
$$

where, FS is factor of safety, $c^{\prime}$ is effective cohesion, $W_{i}$ is the weight of soil at slice $i, r_{u}$ is excess pore water pressure ratio, $\phi^{\prime}$ is internal friction angle.

Finite element method is known as the advanced method in estimating slope stability. Clough and Woodward [16] had introduced finite element method. This method could be implemented to solve several cases in geotechnical engineering, especially related to embankment, stress-strain, and soil mass deformation. The results obtained from finite element method is strongly depended on the performance and the suitability of soil model used in the analysis. Finite element method is a method which implemented the meshing elements. A smaller meshing size means a larger total amount of elements. Therefore, fine elements are needed to obtain a better result. In geotechnical engineering problem, the soil behaviour can be modelled using several modelling concepts. Brinkgreve et al. [17] mentioned that MohrCoulomb model is one of soil models, which is widely used to analyse stability problem, such as slope stability. Slope failure could occur due to the relative movement of soil particle. Mase et al. [8] mentioned that shear strength parameter in soils including cohesion $(c)$ and internal friction angle $(\phi)$ are important in the use of Mohr-Coulomb model.

Several researchers had investigated the slope stability using both limit equilibrium method and finite element method. Griffiths and Lane [17] presented a study of slope stability using finite element method. In general, Griffiths and Lane [18] stated that finite element method could describe the slope failure mechanism and it could be concluded that finite element method is more reliable than limit equilibrium method in estimating slope stability. Gupta et al. [19] studied an analysis of Surabhi Resort Landslide using finite element method and reached a conclusion that the crown portion of the landslides is highly unstable. The performance of finite element method is also reliable. The prediction yielded by finite element method is generally consistent with the field evidence. Rawat and Gupta [20] implemented both methods to observe the performance of nailed installed as slope reinforcement. $F S$ resulted from limit equilibrium method tends to be larger than $F S$ from finite element method. However, Rawat and Gupta [20] had reached a conclusion that the most stable slope from both analyses is found on the reinforced slope nail inclination. Park et al. [21] implemented Bishop Simplified Method [15] in studying the reduction of slope stability due to the Gyeongju 5.8 $\mathrm{M}_{\mathrm{L}}$ Earthquake. Park et al. [21] mentioned that the implementation of Bishop Simplified Method could be reliable to present the slope stability changes during the Gyeongju 5.8 ML Earthquake. Park et al. [21] also proposed that the correlation between slope stability and peak ground acceleration can be used as the reference for performing on-site slope stability evaluations.

In general, several previous studies had given a conclusion that finite element method and limit equilibrium method could be successfully implemented in predicting the slope stability analysis. The results of finite element method are generally consistent with the field evidence. The comparison results between limit equilibrium method and finite element method could be performed to identify slope stability in detail.

\subsection{Methodology}

The framework of this study is presented in Figure 3. This study is aimed to investigate the hydrological aspect and slope stability along Muara Bangkahulu River of Bengkulu City, especially in Semarang Segment. This study was initiated by collecting several important data, i.e. primary data and secondary data. The primary data included the slope geometry, the soil properties, and the normal water level (before flood). The slope geometry could be obtained from the site investigation after the flood. The normal water level had been recorded periodically. Therefore, the water level in the normal condition could be obtained. The undisturbed soil sampling was performed along Semarang Segment. 10 cross-sections had been investigated. Furthermore, soil physical properties and soil engineering properties were investigated by performing the laboratory tests. The observation to the erosion and sedimentation characteristics were also performed. The secondary data used in this study were the rainfall intensity in Semarang Segment before the flooding occurred. Rainfall intensity within 10 years, i.e. 2009 to 2018 was used in this study.

After the data collection, the erosion and sedimentation analyses were performed. The analysis also led to determine the possible increase of water level due to the rainfall intensity. Furthermore, the slope

\footnotetext{
Corresponding author: $\underline{\text { lmase } @ \text { unib.ac.id }}$
} 
stability analysis is performed. In this study both limit equilibrium method [15] and finite element method [17] were employed. This study also considered the comparison of slope stability under normal and critical conditions. Normal condition was defined as the normal water level condition, whereas the critical condition was defined as the maximum water level condition due to the rainfall.

Several parameters including $F S$ and deformations were observed in this study. The results were then interpreted into contour maps describing slope stability in Semarang Segment. In general, this study is expected to provide a better understanding on slope stability during the flood, especially in Semarang Segment. The results could recommend the local government to consider the flood impact in Bengkulu City.

\section{Results and Discussion}

\subsection{Erosion and Sedimentation in Semarang Segment}

The average of monthly rainfall intensity is presented in Figure 4. In general, the average monthly rainfall intensity during past 10 years in Bengkulu City is about $200.5 \mathrm{~mm}$. The maximum rainfall intensity occurred in February, whereas the minimum one occurred in September. In this study, the rainfall intensity was used to estimate raining erosivity [22] or $R$ by this following equation,

$$
R=2.21 \cdot I^{1.36}
$$

where, $R$ is the raining erosivity index and $I$ is monthly rainfall intensity.

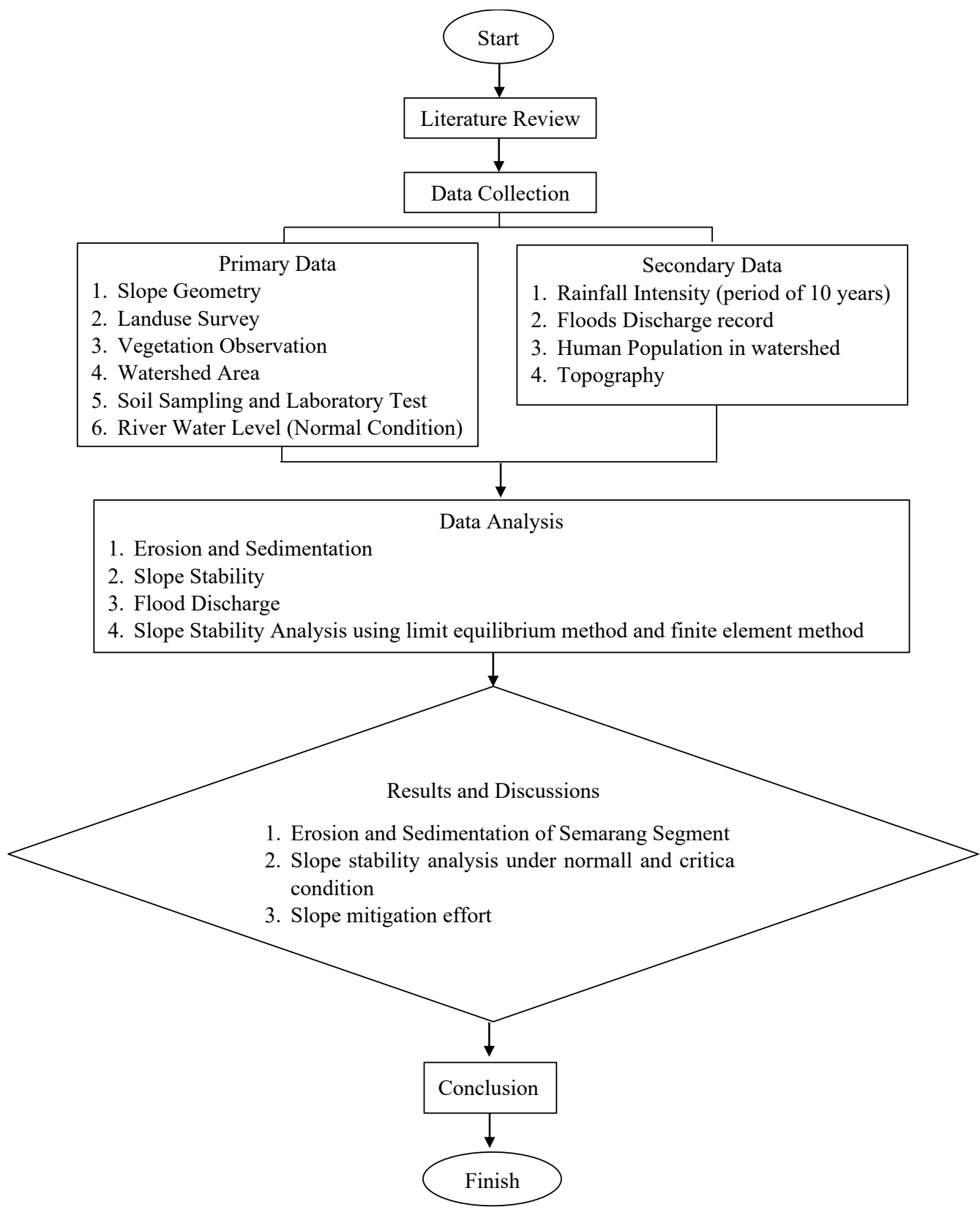

Fig. 3. Flow chart of this study

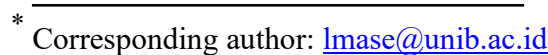




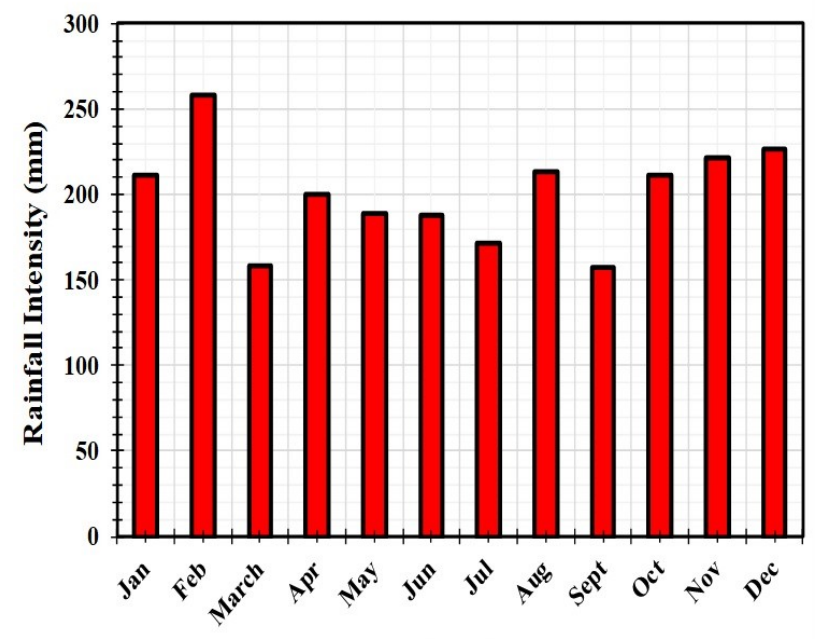

Months

Fig.4. The average of monthly rainfall intensity [11]

The estimation of $R$ values is presented in Table 2 . In Table 2, it can be seen that the larger average of monthly rainfall intensity means the larger erosivity index. The results also showed that the Annual Rainfall Erosivity within past 10 years is about $1572.392 \mathrm{~mm}$. The estimation of soil erodibility is estimated by this following equation,

$$
K=\frac{1.292 \cdot\left(2.1 \cdot M^{1.14}\left(10^{-4}\right)(12-a)+3.25(b-2)+2.5(c-3)\right)}{100}
$$

where, $K$ is soil erodibility value, $M$ is particle size, $a$ is organic content $(\%), b$ is soil structure class, and $c$ is soil permeability (cm/hour).

The result of soil erodibility analysis is presented in Table 3. In this study, ten samples from Semarang Segment were studied. Based on Kironoto [23], the level of erodibility Semarang Segment was generally very high. It indicated that the soil texture in Semarang Segment is relatively easy eroded.

Table 2. Erosivity Index (R)

\begin{tabular}{|c|c|c|c|}
\hline No. & Months & $\begin{array}{c}\text { Average of } \\
\text { Monthly Rainfall } \\
\text { Intensity (cm) }\end{array}$ & Erosivity Index (R) \\
\hline 1 & January & 21.110 & 139.861 \\
\hline 2 & February & 25.780 & 183.543 \\
\hline 3 & March & 15.820 & 94.474 \\
\hline 4 & April & 20.030 & 130.220 \\
\hline 5 & May & 18.900 & 120.332 \\
\hline 6 & June & 18.770 & 119.208 \\
\hline 7 & July & 17.110 & 105.102 \\
\hline 8 & August & 21.320 & 141.756 \\
\hline 9 & September & 15.760 & 93.987 \\
\hline 10 & October & 21.170 & 140.402 \\
\hline 11 & November & 22.160 & 149.406 \\
\hline 12 & December & 22.670 & 154.101 \\
\hline \multicolumn{4}{|c|}{ Annually Rainfall Erosivity } \\
\hline
\end{tabular}

The average value of soil loss $(A)$ in Semarang segment was estimated by using Equation 1. Parameters of erosivity and erodibility had been estimated. Other parameters such as $L_{S}, C$, and $P$ were determined based on the field observation. The field observation to the Semarang Segment reveals that the slope inclination is generally less than $8 \%$ and $L_{S}$ is about $0.4 . C$ and $P$ are the parameters reflecting the vegetation and soil conservation, respectively. For Semarang Segment, $C$ could be assumed as 0.2. It is because semarang Segment area was composed by mixed areas between housing and farming areas with medium density. $P$ values were obtained based on the field observation to the conservation action.

Table 3. Erodibility Index (K)

\begin{tabular}{|c|c|c|c|c|c|}
\hline Sample & $\mathrm{M}$ & $\begin{array}{c}\text { Soil } \\
\text { Structure } \\
\text { Class }\end{array}$ & $\begin{array}{c}\text { Soil } \\
\text { Permeability } \\
\text { class }\end{array}$ & $\mathrm{K}$ & $\begin{array}{c}\text { Erodibility level } \\
{[24]}\end{array}$ \\
\hline 1 & 4700.470 & 4 & 5 & 0.6134 & very high \\
\hline 2 & 2531.600 & 4 & 6 & 0.4117 & rather high \\
\hline 3 & 4491.680 & 4 & 6 & 0.6151 & very high \\
\hline 4 & 6366.440 & 4 & 6 & 0.8149 & very high \\
\hline 5 & 3223.970 & 4 & 6 & 0.4499 & high \\
\hline 6 & 1816.460 & 4 & 6 & 0.3178 & fair \\
\hline 7 & 3878.890 & 3 & 6 & 0.4805 & high \\
\hline 8 & 5686.670 & 3 & 6 & 0.6633 & very high \\
\hline 9 & 7908.540 & 3 & 6 & 0.9426 & very high \\
\hline 10 & 7858.820 & 4 & 6 & 0.9040 & very high \\
\hline
\end{tabular}

In this study, soil conservation actions included soil benching, grass vegetation, soil cultivation, and no conservation actions were observed in Semarang Segment. Based on the analysis, the average annual soil loss in Semarang Segment is about 7.380 ton/acre or 120.992 ton/year. Percentage of erosion level in Semarang Segment is presented in Figure 5.

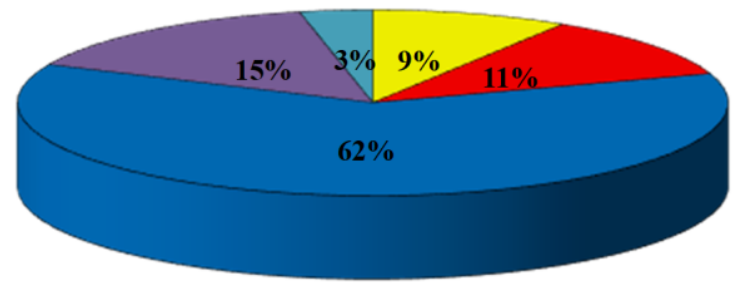

\section{$\square$ Very light $\square$ light $\square$ fair $\square$ hard $\square$ very hard}

Fig. 5. The distribution erosion level in Semarang Segment (in percentage)

In general, the erosion occurred in Semarang Segment varied from very light to very hard. Based on the figure, it can be concluded that the level of erosion in Semarang Segment can be generally categorised as fair level.

The soil textures in Semarang Segment was generally dominated by unconsolidated material. Therefore, based on Arsyad [24] the tolerable loss soil factor was about 8.96. Tolerable Soil Loss (TSL) for Semarang Segment was about 465.91 ton/years. Hence, the erosion index for the Semarang Segment can be obtained by comparing the average soil loss $(A)$ to the tolerable soil loss. For Semarang Segment, the analysis showed that the Erosion Index is about 0.260. Arsyad [24] mentioned that the Erosion Index less than one indicated that the erosion damage is generally tolerable.

\footnotetext{
* Corresponding author: $\underline{\text { lmase@unib.ac.id }}$
} 
However, the soil-water conservation to decrease the erosion is still required. Sedimentation in Semarang Segment is estimated by Equation 2. In this study, the upstream watershed condition has not considered in the sedimentation analysis. Based on field observation the area of Semarang Segment was about 52 acres. Therefore, $S D R$ value for this area was about 0.155 . It indicated that transported sediment was relatively low. This is also caused by the slope geometry in this area. In general, the slope in Semarang Segment has the inclination of $8 \%$. From $S D R$ value, the sediment value $(Y)$ in Semarang Segment could be estimated. In this study, $Y$ is about 58.220 ton/year. The tolerable sediment in this area is about 72.067 ton/year. Similar to the impact of erosion, the sedimentation damage is generally tolerable. However, the soil-water conservation to decrease the erosion is still required.

\subsection{Slope Stability Analysis}

The hydrological analysis to the Semarang Segment was performed in this study. In this research, the maximum discharge due to the rainfall intensity within period of 10 years. The result of hydrological analysis is presented in Table 4. In Table 4, the prediction of water level increase is analysed from the cross section provided in Figure 2. Table 4 also showed that the maximum water level increase ranged from 0.519 to $0.643 \mathrm{~m}$. Furthermore, the increase of water level during the period of 10 years was used in slope stability analysis. In this study, slope stability analysis was performed by implementing limit equilibrium method and finite element method. The factor of safety and possible deformation were analysed under two conditions, i.e. normal and critical conditions.

Table 4. The prediction of maximum water level increase in Semarang Segment within 10 years rainfall period in Semarang Segment

\begin{tabular}{|c|c|c|c|}
\hline Cross Sections & $\begin{array}{c}\text { Cross- } \\
\text { Sectional } \\
\text { Area }\left(\mathrm{m}^{2}\right)\end{array}$ & $\begin{array}{c}\text { Discharge } \\
\left(\mathrm{m}^{3} / \mathrm{s}\right)\end{array}$ & $\begin{array}{c}\text { The increase of } \\
\text { water level }(\mathrm{m})\end{array}$ \\
\hline $1-1$ and $2-2$ & 48.045 & 159.5229 & 0.575 \\
\hline $3-3$ and $4-4$ & 31.5 & 104.5888 & 0.573 \\
\hline $5-5$ and 6-6 & 40.8 & 135.4674 & 0.607 \\
\hline $7-7$ and $8-8$ & 41.6 & 139.1245 & 0.643 \\
\hline 9-9 and $10-10$ & 31.5 & 105.3467 & 0.519 \\
\hline
\end{tabular}

The recapitulation of slope stability analysis from both limit equilibrium method (simplified bishop) and finite element method is presented in Table 5. In Table 5, results including factor of safety for normal water level and critical water level and maximum deformation are presented. For normal water level, limit equilibrium method yielded $F S$ of 0.978 to 1.940 , whereas finite element method yielded FS of 0.946 to 2.373. For critical water level, limit equilibrium method resulted in $F S$ of 0.857 to 1.759 , whereas finite element method results in FS of 0.928 to 2.239. In general, $F S$ for critical water level tends to be smaller than $F S$ of normal water level. This was due to the fact that the increase of water level tends to enlarge the excess pore water pressure. It means that there was the reduction of shear strength. This could be the reason why the slope failure happened during the flood. The maximum deformation resulted from finite element method is also presented in Table 5 . In Table 5, the maximum deformations under both water level conditions were observed. In general, the maximum deformation due to normal water level ranged from 1.158 to $3.140 \mathrm{~m}$. Meanwhile, the maximum deformation due to critical water level ranged from 1.509 to $4.912 \mathrm{~m}$.

The results of slope stability analysis were then interpreted in microzonation map. Figure 6 presents the microzonation map of $F S$ under normal water level in Semarang Segment resulted from limit equilibrium method and finite element method. In general, both methods showed that the unsafe to critical area (yellow to red shading) was spreading in the southern part of Semarang Segment, especially in the meander side. This zone was relatively critical to sedimentation and erosion. The erosion and sedimentation could result in the damage of soil structure which was able to reduce soil shear strength. Figure 6 also showed that the housing areas were generally centralised on this vulnerable zone. Figure 7 presents the microzonation of $F S$ due to critical water condition. In general, the vulnerable zone to slope failure due to the critical water level are larger than the normal water level. Based on the analysis, the area would be more vulnerable to undergo slope failure could be found on the southern part of Semarang Segment, the middle part of Semarang Segment, the northern part of Semarang Segment, and the western part of Semarang Segment. Both methods generally showed the similar tendency in terms of the vulnerable zone. The results showed that during the flood, the housing area would be vulnerable to undergo slope failure. The results also recommended the local government to consider the slope failure in this segment. Figure 8 presents the microzonation maps of deformations in Semarang Segment under normal water level condition and critical water level condition. In this study, the maximum deformation is generated from the slope stability analysis using finite element method. Figure 8 was also separated two zonations i.e. the moderate deformation zone and high deformation zone. The moderate deformation zone was destined for the deformation ranging from 1 to $2 \mathrm{~m}$, whereas the high deformation zone was for the deformation larger than $2 \mathrm{~m}$.

In general, under the normal water level condition, Semarang Segment was vulnerable to undergo large deformation especially in the eastern and northern parts of Semarang Segment. This was due to the fact that in this zone the loose material transported are very critical to undergo slope failure. In addition, the sloping topographical condition in this section is relatively steeper than other slopes around Semarang Segment. Therefore, the maximum gravity force was relatively larger and it could lead to the slope failure in this area. Under the critical water condition, the large deformation could happen in the middle part of Semarang Segment. During the flood, the river stream tends to scrape away the soil particle on the slope. It would be a path for the

\footnotetext{
* Corresponding author: $\underline{\text { lmase } @ \text { unib.ac.id }}$
} 
water to initiate the significant infiltration into the slope. At this condition, the excess pore water pressure would play important role in reducing the slope stability. Therefore, in this zone, the deformation could be larger.

Table 5. Summary of slope stability analysis

\begin{tabular}{|c|c|c|c|c|c|c|}
\hline \multirow{3}{*}{$\begin{array}{c}\text { Cross } \\
\text { Sections }\end{array}$} & \multicolumn{4}{|c|}{ Factor of Safety $(F S)$} & \multicolumn{2}{c|}{ Maximum Deformation (m) } \\
\cline { 2 - 7 } & \multicolumn{2}{|c|}{ Normal Water Level } & \multicolumn{2}{c|}{ Critical Water Level } & \multicolumn{2}{c|}{ Finite Element } \\
\cline { 2 - 7 } & Simplified Bishop & Finite Element & Simplified Bishop & Finite Element & $\begin{array}{c}\text { Normal Water } \\
\text { Level }\end{array}$ & $\begin{array}{c}\text { Critical } \\
\text { Water Level }\end{array}$ \\
\hline $1-1$ & 1.469 & 1.489 & 1.359 & 1.469 & 2.464 & 1.512 \\
\hline $2-2$ & 1.364 & 1.349 & 1.258 & 1.346 & 1.158 & 1.509 \\
\hline $3-3$ & 1.624 & 1.601 & 1.587 & 1.598 & 1.760 & 2.068 \\
\hline $4-4$ & 1.879 & 2.373 & 1.759 & 2.239 & 2.305 & 1.491 \\
\hline $5-5$ & 1.524 & 1.024 & 1.482 & 1.011 & 1.471 & 4.912 \\
\hline $6-6$ & 1.357 & 1.392 & 1.259 & 1.338 & 1.357 & 2.731 \\
\hline $7-7$ & 1.840 & 2.555 & 1.741 & 2.053 & 1.308 & 2.127 \\
\hline $8-8$ & 0.978 & 0.946 & 0.857 & 0.928 & 2.473 & 1.773 \\
\hline $9-9$ & 1.469 & 1.638 & 1.387 & 1.482 & 2.650 & 1.637 \\
\hline $10-10$ & 1.940 & 2.183 & 1.758 & 2.183 & 3.140 & 1.950 \\
\hline
\end{tabular}

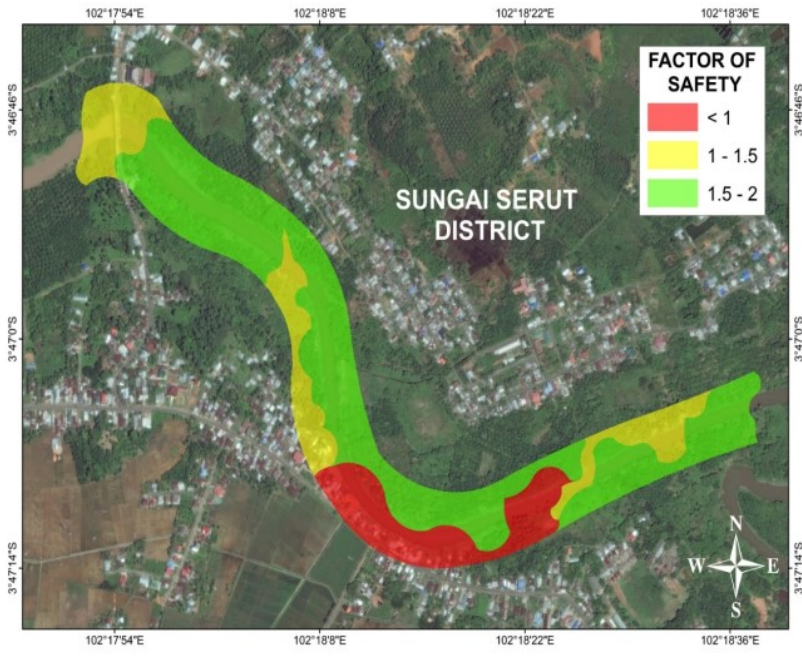

(a)

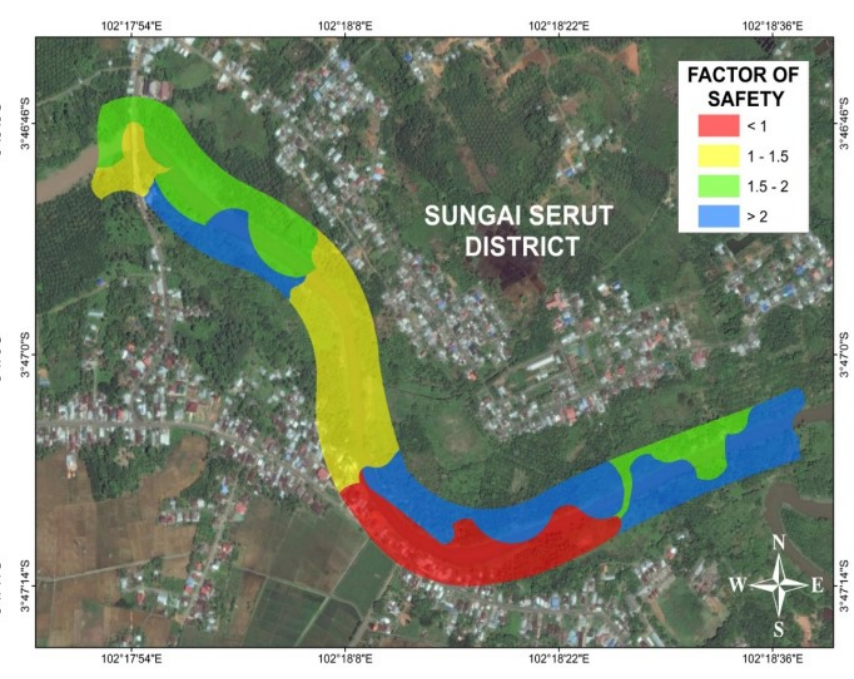

(b)

Fig. 6. The microzonation map of $F S$ in Semarang Segment under normal water level condition (a) limit equilibrium method (Simplified Bishop) (b) finite element method

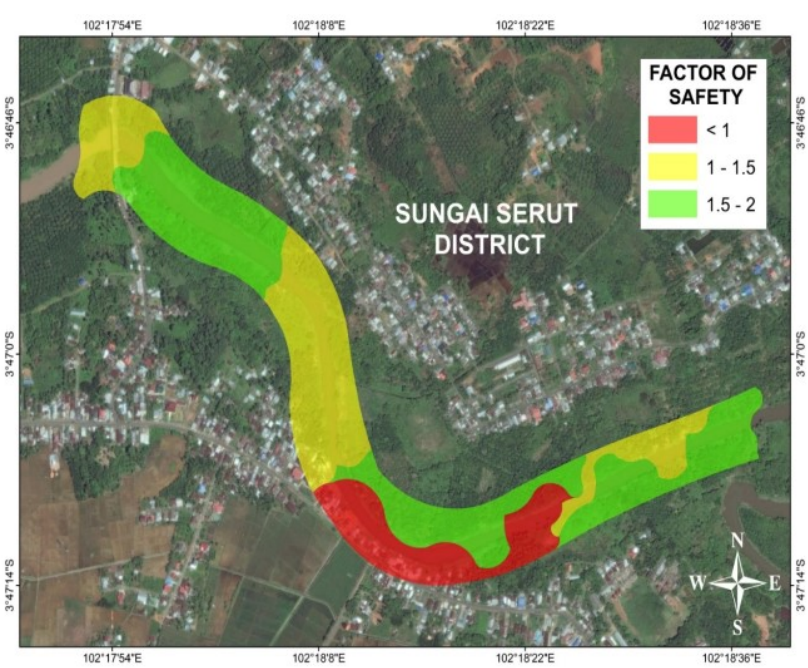

(a)

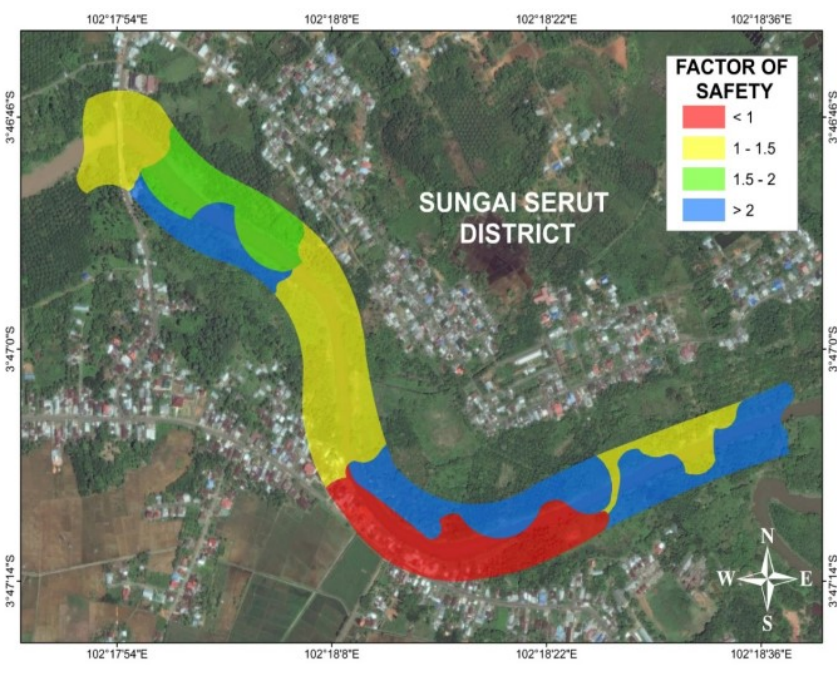

(b)

Fig. 7. The microzonation map of FS in Semarang Segment under critical water level condition (a) limit equilibrium method (Simplified Bishop) (b) finite element method

\footnotetext{
* Corresponding author: $\underline{\text { lmase } @ u n i b . a c . i d}$
} 


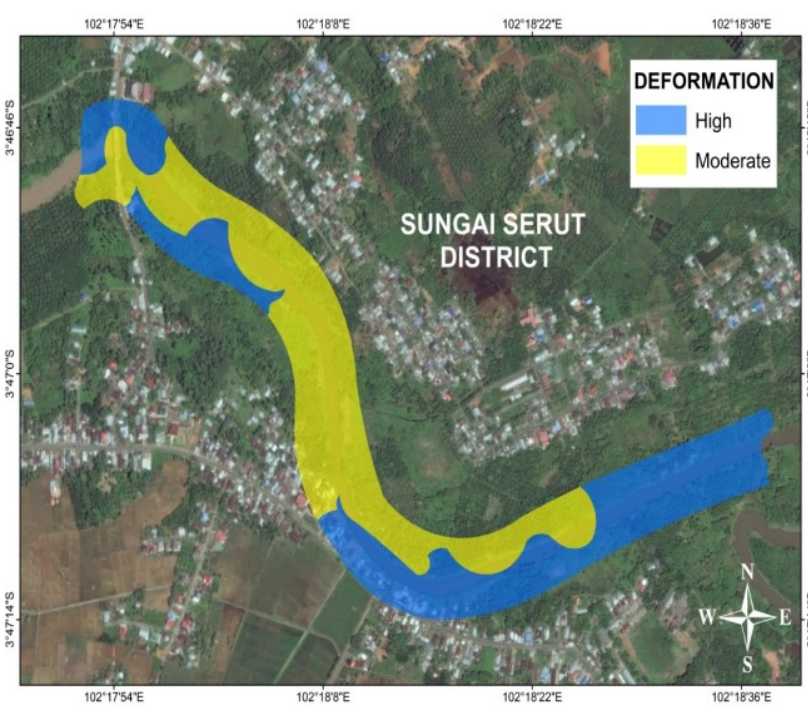

(a)

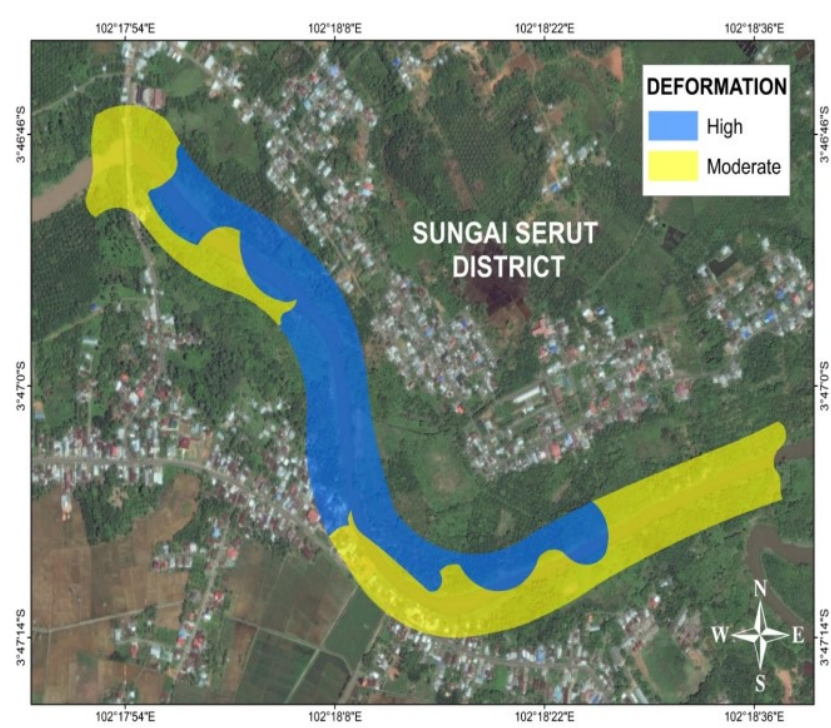

(b)

Fig. 8. The microzonation map of maximum deformation in Semarang Segment under (a) normal water level condition (b) critical water level condition

For other areas, the steeper slope tends to be more difficult for the infiltration. It might be the reason why the deformation in the northern and eastern parts of Semarang Segment is relatively moderate during the critical water level condition. Overall, the results of finite element analysis describe that the housing areas in Semarang Segment could undergo the significant soil damage in terms of maximum deformation on both water level condition. The implementation of slope stability analysis based on the hydrological analysis output, which is combined to the geotechnical analysis could describe slope stability in this area. The results of this study could help the local government to reduce the possible impact of slope failure due to flood in the Semarang Segment of Bengkulu City, Bengkulu, Indonesia.

\subsection{Slope Mitigation Effort}

Based on the results of analysis, it can be seen that slope stability is depending on the increase of water level due to the flood discharge. For Semarang Segment, the slope mitigation effort is important to implement. The texture of soil particles in Semarang segment is relatively fine. This is very vulnerable to undergo erosion. The eroded materials from the high terrain could also dump on the river watershed. For this matter, the slope protection using soil bioengineering could be the solution. The vegetation along the slope river could control the amount of eroded materials, which flows to the river.

The erosion due to the river stream could be another issue in Semarang Segment. The river stream could scrape away the toe of river slope. Therefore, the slope river remediation for Semarang Segment could be performed in the study area. The Semarang Segment area is now a crowded area in Bengkulu City. This area is chosen by the people because the access to the downtown area is relatively close. However, the flood can happen frequently in this area. The education to the local people to take care of Muara Bangkahulu River is also important. The less awareness of the local people to maintain the slope river could be the problem in the future if it is not handled. The local government (Bengkulu City) and all involved stakeholders could collaborate together to reduce the potential causes of slope failures and floods in Bengkulu City, especially in Semarang Segment.

\section{Concluding Remarks}

This paper presents the environmental impact to the Semarang Segment of Muara Bangkahulu Subwatershed, Bengkulu City, Indonesia. The environmental and hydrological analyses such as estimations of erosion and sedimentation were presented in the analysis. The estimation of maximum increase of water level was also studied. The slope stability analysis along Muara Bangakhulu River of Semarang Segment on the basis of water level change under the normal condition and flood discharge was performed. In general, the erosion and sedimentation in Semarang Sub-watershed had occurred. The prediction of erosion and sedimentation in Semarang Segment showed that the water conservation was very important. Unhandled erosion and sedimentation could lead the Semarang Segment would undergo the huge impact of inundation due to the flood, such as the 2019 Bengkulu Flood. The increase of water level due to the rainfall intensity also would endanger slope along Semarang Segment. Slope stability analysis showed that housing area in Semarang Segment could be unstable, since the minimum required $F S$ was not fulfilled. The deformation in this segment was also large. Therefore, the slope protection combined with the water conservation are very important to be implemented in Semarang Segment. The results of this study also bring a recommendation to consider the slope countermeasure in the study area to reduce the possible impact of slope failure in this area.

\footnotetext{
* Corresponding author: $\underline{\text { lmase@unib.ac.id }}$
} 


\section{Acknowledgement}

This study is supported by KURITA-AIT Research Grant (KARG) (2018) from KURITA Water Environmental Foundation (KWEF), Japan. The author would like to thank to Hydrology Laboratory and Soil Mechanics Laboratory of the University of Bengkulu, Bengkulu, Indonesia, for the soil sampling and properties tests. The author also would like to thank Mr. Redico Bhedro for the assistance in analysis of slope stability. The gratitude is also addressed to Ms. Ceri Eliesa Suhartini for the assistance in composing the slope stability map.

\section{References}

1. L.Z. Mase. International Journal of Technology 9, 5, 910 (2018)

2. L.Z. Mase, G. Fathona, Teknosia 3, 1, 40 (2017).

3. Badan Penanggulangan Bencana Daerah, (2019). The report of the 2019 Bengkulu Flood. Badan Penanggulangan Bencana Daerah, Bengkulu, Indonesia. (in Indonesian)

4. A.K Howard, Geotechnical Testing Journal 7, 4, 216 (1984)

5. W.H. Winschmeier, D.D. Smith. Predicting Rainfall Erosion Losses: A Guide to Conservation Planning (Washington D.C, US Department of Agriculture, 1978)

6. L.D. Meyer, W.H. Wischmeier, W.H. Daniel, Transactions of the ASAE 14,1, 138 (1971).

7. F.W. Citra, Supriyono, Edwar, W. Sugandi, Georafflesia 2, 1, 77 (2018)

8. L.Z. Mase, Hardiansyah, K. Amri. Progress Report : Study of Performance Comparison Between Controlling Method and Reinforcement Method for Slope Protection in Bengkulu Tengah, Bengkulu, Indonesia (Dept of Civil Engineering, University of Bengkulu, Bengkulu, Indonesia, 2019) (In Indonesian)

9. K. Amri, A. Halim, M.F. Barchia, APCBEE procedia 10, 1, 235 (2014)

10. N.S. Putrie, D. Susiloningtyas, Pratami. IOP Conference Series: Earth and Environmental Science 284, 1, 012007 (2019)
11. Mase, L.Z., 2019. Final Report: A study of climate change and environmental damage impacts of Muara Bangkahulu River Watershed to evaluate the policy in conserving the sub watershed of Bengkulu Hilir for the local citizen in Bengkulu City, Indonesia, Kurita Water and Environment Foundation (KWEF), Tokyo, Japan, Indonesia (2019).

12. P. Van Santen, P.G.E.F. Augustinus, B.M. JanssenStelder, S. Quartel, and N.H. Tri. Journal of Asian Earth Sciences 29, 4, 566 (2007).

13. K. Auerswald, Proceedings of the 5th International Symposium on River Sedimentation, Karlsruhe, Germany (1992)

14. Asdak, C. (2002). Hidrologi dan Daerah Aliran Sungai, (Gadjah Mada University Press, Yogyakarta, 2002)

15. A. W. Bishop. Geotechnique 5, 1, 7 (1955)

16. R.W. Clough, R.J. Woodward. Journal of Soil Mechanics \& Foundations Division ASCE 93, 4, 529 (1967)

17. R.B.J. Brinkgreve, W.M. Swolfs, E. Engin, D. Waterman, A. Chesaru, P. Bonnier, V. Galavi, PLAXIS 2D Reference manual (Delft University of Technology and PLAXIS bv The Netherlands, 2011).

18. D.V. Griffiths, P.A. Lane. Geotechnique, 49, 3, 387 (1999)

19. V. Gupta, R.K. Bhasin, A.M. Kaynia, V. Kumar, A. S. Saini, R.S. Tandon, T. Pabst, Natural Hazards and Risk 7, 5, 1677 (2016)

20. S. Rawat, A.K. Gupta. International Journal of Geosynthetics and Ground Engineering 2(4), 34 (2016)

21. S. Park, W. Kim, J. Lee, Y. Baek, Sustainability, 10, 10, 3441 (2018)

22. J. Lenvain, Critical study of the universal soil loss equation and its suitability to evaluate the soil conditioning technique in the wet tropics (Thesis, Agricultural Faculty, Universiteit Ghen, Belgium, 1985) (in Dutch)

23. B.A. Kironoto, Dinamika Teknik Sipil 8, 1, 59 (2007).

24. S. Arsyad, Soil Water and Conservation (Institute Pertanian Bogor, Bogor, Indonesia, 2010). (in Indonesian

\footnotetext{
* Corresponding author: $\underline{\text { lmase@ } @ \text { unib.ac.id }}$
} 